\title{
Fundamentos históricos e teóricos da noção de soberania: a contribuição dos "Papas juristas" do século XIII
}

\author{
Historical and theoretical foundations of the notion \\ of sovereignty: the contribution \\ of "jurist Popes" in the $13^{\text {th }}$ century
}

Raquel Kritsch

\section{Introdução}

O termo soberania é um vocábulo que tem sido umbilicalmente vinculado, desde pelo menos o século XVI, na tradição ocidental, à noção de Estado moderno. Uma ideia que remonta pelo menos à clássica formulação oferecida por Jean Bodin, de que a soberania consistiria na capacidade (do Estado) de deter o poder de jurisdição exclusiva sobre um determinado território (Bodin, 1994: 50

\footnotetext{
Este texto está vinculado ao Projeto de Pesquisa "Direitos humanos universais e Estados nacionais: fundamentos históricos e problemas teóricos II", financiado pelo CNPq e desenvolvido junto ao Grupo "Estudos em Teoria Política" (GETEPOL-CNPq).

Raquel Kritsch é doutora pela Universidade de São Paulo e professora de Ciência Política do Departamento de Ciências Sociais e do Programa de Pós-Graduação em Ciências Sociais da Universidade Estadual de Londrina, Londrina, Brasil (kritsch@uel.br).

Artigo recebido em 20 de abril de 2010 e aprovado para publicação em 27 de outubro de 2010.
}

Est. Hist., Rio de Faneiro, vol. 23, $n^{o}$ 46, p. 261-279, julho-dezembro de 2010. 


\section{Raquel Kritsch}

e seguintes). A vinculação entre as duas noções se propagou a tal ponto que hoje Estado e soberania são termos comumente utilizados, sobretudo no vocabulário da área da ciência política, como sinônimos, especialmente quando se deseja expressar a extensão e o poder de um Estado.

A sedimentação desta conotação, que obviamente tem a sua própria história, não nos auxilia, contudo, a compreender a origem e os fundamentos desta ideia tão cara ao pensamento político moderno: a noção de soberania. Muito pelo contrário. $\mathrm{O}$ entrelaçamento das duas ideias terminou obscurecendo as raízes e 0 sentido primitivo da ideia de soberania que, ao contrário do que sustentaram inúmeros estudiosos, não nasceu como uma ideia leiga, destinada a nomear o poder do governante temporal, fosse ele o rei, o príncipe ou o imperador.

Muito antes de se formarem e de se consolidarem os chamados Estados territoriais modernos, surgidos na Europa a partir de fins da Idade Média, já circulava entre os pensadores políticos medievais uma clara noção deste fenômeno que os modernos nomeariam soberania. Embora não aparecesse na maior parte dos escritos medievais com este nome, os atributos, a função e o significado da noção de soberania já eram há muito indicados pelos juristas, tanto civilistas quanto canonistas, que a expressavam por meio de vários outros nomes, como plenitudo potestatis, summa potestas etc.

Esses profissionais do direito - que surgiram no seio do movimento de recuperação do direito romano e que seriam treinados na profissão nas nascentes universidades, fundadas nos grandes centros urbanos europeus a partir de meados do século XII - iriam atribuir tais poderes supremos ora ao sumo pontífice, ora ao imperador do Sacro Império Romano-Germânico do Ocidente e ora aos reis, como aconteceria pouco depois com o rei francês Filipe II Augusto (11801223).

Assim, a gênese do conceito de soberania é demorada e vai ligar-se, ao final deste processo e de maneira indissolúvel, aos Estados territoriais modernos em formação. Ela faz parte de um processo de transformação jurídica e política, no qual é desenhado um novo mapeamento do poder e das lealdades no continente europeu. A mudança não se dá ao mesmo tempo nem com a mesma velocidade em toda a Europa. A consolidação da autoridade real, a centralização administrativa e a burocratização das funções públicas ocorrem mais cedo na Inglaterra do que na maior parte do continente. A influência do Império, assim como a da Igreja, se exerce de forma desigual nas várias regióes do Velho Mundo.

Por trás de toda essa diversidade, no entanto, alguns elementos comuns permitem falar num processo geral de transformação: o surgimento de núcleos de poder duradouros e geograficamente estáveis, o desenvolvimento de instituições permanentes e impessoais e a concentração das lealdades na figura do rei. A conformação desse novo sistema de poder tem como contrapartida a constitui- 
ção de uma nova ordem jurídica. Essa ordem redefine os vínculos de comando e obediência, constitui unidades políticas como áreas de jurisdição exclusiva e estabelece, entre essas unidades, relações de igualdade num sentido preciso: forte ou fraca, pequena ou grande, nenhuma se reconhece como subordinada a outra.

Todas essas questões podem ser entendidas como disputas de jurisdição. Trata-se de saber quem julga e quem pune delitos civis ou violações de normas religiosas, o que já implica a distinção entre duas ordens normativas e duas classes de autoridade. Trata-se de estabelecer a extensão de poderes, como, por exemplo, o de tributar. O frade é subordinado apenas ao Papa ou é também súdito do rei e, portanto, pessoa tributável?

Os poderes de legislar, de mudar a lei, de resolver como última instância e de controlar o uso da violência constituem o que os autores modernos nomearam soberania. Os reis, os Papas e imperadores com certeza não tinham desenhada na mente, com todos os traços, a imagem do mundo que estavam construindo. Tinham, porém, certamente, uma visão organizada de suas ambições e dos objetos em disputa. Aceitos estes pontos, falar em soberania (como ponto de convergência dos grandes conflitos de jurisdição) no período medieval deixa de ser um anacronismo. ${ }^{1}$

\section{Regnum e sacerdotium: as disputas de jurisdição e seus desdobramentos}

Walter Ullmann lembra-nos que uma das formulações mais antigas de que se tem notícia do princípio da autonomia territorial vinculada ao direito de jurisdição exclusiva pode ser encontrada numa lei diocesana, sancionada no I Concílio Ecumênico de Constantinopla, em 381, constante nas compilações legais da Ecclesia. Esta lei diocesana - oriunda, por sua vez, do antigo direito público romano - regulamentava a jurisdição dos bispos em suas dioceses, de acordo com o princípio territorial: seus domínios (e todos os demais direitos a eles associados, sacramentados por meio da investidura na função) estendiam-se aos limites geográficos de cada diocese (Ullmann, 1978: 17-19).

Embora disputas jurisdicionais entre o Papado e o Império tivessem ocorrido ao longo de todo o período medieval, o debate em torno do direito de jurisdição, no entanto, iria se acirrar - até desembocar na moderna noção de soberania - especialmente a partir do século XI, com a querela das investiduras.

A questão das investiduras consistiu basicamente numa disputa entre 0 Papa Gregório VII (1073-85) - que, na tentativa de moralizar a Ecclesia, impôs aos prelados um novo código eclesiástico, cujo objetivo era por fim à prática da simonia e do nicolaísmo dentro da Igreja e que ficou conhecido como a reforma gregoriana $^{2}$ - e o imperador Henrique IV (1056-1106), rei alemão e imperador 
dos romanos. A resposta do imperador às medidas de Gregório VII foi dada num sínodo por ele convocado, em Worms, no ano de 1076: com os votos de 24 bispos alemães e dois italianos, o Papa foi deposto.

O pontífice respondeu, recusando ao imperador o direito de governar a Germânia e a Itália e ordenou a todos os cristãos que lhe negassem obediência desde o século IV (394) não ocorrera mais uma excomunhão na Igreja. O imperador ficava assim impedido, entre outras coisas, de receber os sacramentos.

A querela entre o Papa e o imperador prosseguiu com seguidas retaliações e desagravos de parte a parte e só foi terminar com um acordo selado por um outro papa e um outro imperador. Em 1122, depois de muita relutância - e já sob o pontificado de Calixto II (1119-1124) -, o imperador Henrique V (1106-1125), herdeiro de Henrique IV, pôs fim às negociações, assinando a concordata de Worms.

Segundo o tratado, o imperador renunciava à investidura dos prelados na função mediante o báculo e o anel, mas conservava o direito de vigilância sobre as eleições eclesiais no reino alemão, reservando-se ainda o poder de decidir eleições contestadas. O imperador conservou também o direito de conceder a investidura dos bens temporais (regalia) mediante o cetro, podendo fazê-lo, em território alemão, entre a eleição e a consagração dos escolhidos. Na Itália e na Borgonha as eleições episcopais eram livres e, por isso, o bispo só precisava prestar juramento de fidelidade ao imperador seis meses depois da consagração. ${ }^{3}$

Entre as consequências relevantes da disputa estavam a libertação da Igreja do cesaropapismo germânico e o reforço do prestígio e da autoridade moral da instituição papal. A questão das investiduras, como foi exposto, girou em torno, portanto, do problema de quem teria poder para nomear os bispos e investir o clero na função. Isto é, em torno de quem tinha autoridade legítima para executar esta ou aquela ação. A querela indicava assim, com clareza, uma disputa entre o Império e o Papado por competências jurisdicionais.

Nesse momento, contudo, o problema da soberania se colocava não apenas para o imperador ou para o papa, mas para todos os poderes que pretendiam obter a supremacia nos confrontos com outros disputantes. E, de modo um pouco diferente do que veio a ocorrer com a noção de Estado moderno, soberania, nesse sentido, não era incompatível com a ideia de uma comunidade universal cristã. A luta pela supremacia do poder de mando não envolvia ainda, neste momento, limites territoriais muito definidos e era reivindicada tanto por governantes seculares quanto por governantes espirituais.

Aliás, os avanços teóricos mais substanciais no que respeita à supremacia de poder seriam formulados não pelos juristas do imperador, e sim pelos legistas da Igreja, que trabalhavam incessantemente para justificar a plenitude de poder do sumo sacerdote sobre os demais poderes seculares. Este movimen- 
to alcançou seu ápice no século XIII. ${ }^{4}$ Do ponto de vista do desenvolvimento das ideias políticas, o período foi marcado pela consolidação da tendência ao fortalecimento do poder papal, existente na Ecclesia desde a reforma gregoriana. Os ocupantes da cadeira pontifícia passaram a reivindicar, com maior ou menor coerência, a supremacia e o controle das duas espadas: a espiritual e a temporal. O sumo sacerdote reclamava a jurisdição de facto e de iure sobre a comunidade cristã.

A afirmação desse pensamento, denominado pelos especialistas de hierocrático - que culminou, um século depois, na defesa de uma espécie de "monarquia papal absoluta" por Egídio Romano, em 1304 (Romano, 1929) -, deu-se de forma gradual e nem sempre clara. Na tentativa de se impor ao regnum, cuja figura máxima era o imperador, a Igreja selava alianças com reis e autoridades locais e, com isso, fortalecia indiretamente esses poderes, que seriam mais tarde um dos sustentáculos do chamado Estado moderno.

Também o fato de o trono imperial ter ficado vago por um bom período, depois da morte de Frederico II, em 1250 - em razão da incapacidade de seus herdeiros de exercer um adequado controle sobre as possessões imperiais -, contribuiu sobremaneira para o avanço das pretensões temporais da Igreja. Pois, na ausência do imperador, a quem os inúmeros reis e senhores locais deviam vassalagem, a Igreja era a única instituição de caráter "universal” a ligar a cristandade e seus fiéis. Quando finalmente o Império voltou a ter um representante legal - o que ocorreu com a eleição do rei alemão Rodolfo I de Habsburgo (1273-1291)-, a Ecclesia já tinha estendido vários de seus braços a inúmeros âmbitos de jurisdição, antes exclusivos do poder temporal.

Todavia, o fato realmente importante era o de que, nessa disputa - que havia começado bem antes desse "vácuo de poder" e se estenderia para muito além dele -, a Igreja, ao buscar legitimar política e juridicamente sua aspiração de constituir-se como um poder supremo capaz de governar toda a cristandade, acabou refinando o aparato conceitual disponível. No movimento de procurar definir, sob bases legais, a figura e a função de seu representante maior, o sumo pontífice, a corporação religiosa criou preceitos jurídicos e políticos que consolidaram a ideia da soberania.

Essa ainda incipiente noção de soberania, cujos primeiros contornos a Ecclesia procurava delinear, seria rapidamente apropriada, vale lembrar, por um novo conjunto de interesses e pretensões que entravam em cena, o dos Estados territoriais nascentes. Antes, porém, que esse movimento histórico que constituiu o Estado moderno se tornasse realidade, as disputas entre regnum e sacerdotium (isto é, entre Império e Papado) pela pretensão de supremacia ganhariam ainda alguns acréscimos teóricos e práticos relevantes para o desenvolvimento das ideias políticas (Watt, 1991: 367 e seguintes). 
Entre as mais enfáticas contribuições, estão os avanços conceituais promovidos pelo polêmico Papa Inocêncio III (1198-1216), que dedicou todo seu pontificado à tarefa de fortalecer e consolidar as pretensões hierocráticas da Igreja. O novo Papa assumiu o posto em meio à contenda com o Império, chefiado pelo filho de Frederico I, o Barba-Ruiva, o príncipe herdeiro Henrique VI (1190-1197).

Embora a morte prematura de Henrique VI tivesse proporcionado um período de trégua entre os dois poderes, Inocêncio III empenhava-se em fundamentar melhor as pretensões pontifícias. Numa decretal, intitulada Solitaedirigida ao influente imperador bizantino, Aleixo III (1195-1203), que protestara em documento oficial contra as reivindicações do pontífice -, Inocêncio III fez uma defesa cuidadosa da primazia do sacerdócio sobre os poderes temporais.

Em resposta a Aleixo, que sustentava deverem os fiéis se submeter às autoridades terrenas constituídas, ${ }^{5}$ Inocêncio III argumentava que, mesmo tendo os reis mandado nos sacerdotes, como consta do Antigo Testamento, agora era diferente. Pois, na época do Novo Testamento, o Cristo, Sumo Sacerdote da Nova Aliança, que redimiu os homens por meio de sua paixão e morte, teria deixado na terra um vigário - Pedro e seus sucessores - para prosseguir a tarefa que havia começado.

O sacerdotium, ou o papado, teria assim, segundo a decretal pontifícia, a função de salvar as almas, tarefa bem mais relevante, quando consideradas sua finalidade e transcendência, do que aquela exercida pelo poder régio. Daí outrora, explicava Inocêncio, os reis terem exercido um poder supremo e exclusivo sobre toda a sociedade. ${ }^{6}$

Mais adiante, no $\int 4$ da Solitae, Inocêncio III recorria ao Gênesis ${ }^{7}$ para sustentar seu ponto de vista, interpretando a passagem bíblica nos seguintes termos:

Deus fez, portanto, duas grandes luminárias na abóbada celestial, isto é, na Igreja Universal, quer dizer, Ele instituiu duas grandes dignidades, que são a autoridade pontifícia e o poder real. Mas a que dirige os dias [o sol], isto é, as coisas espirituais, é maior, e a que preside à noite [a lua], pelo contrário, é menor, a fim de que se saiba quão grande é a diferença que existe entre os pontífices e os reis, à semelhança do que se passa com o sol e a lua (Solitae. Souza \& Barbosa, 1997: 130).

E, no $₫ 6$, acrescentava mais um argumento: a conhecida concessão de Cristo a São Pedro, pedra fundadora da Igreja, a quem caberia o poder de ligar e 
desligar no céu e na terra. Reza a passagem: "Eu, eu te digo: Tu és Pedro, e sobre esta pedra edificarei a minha Igreja, e as portas do Inferno não prevalecerão contra ela. Dar-te-ei as chaves do Reino dos céus, e o que ligares na terra ficará ligado nos céus; e tudo o que desligares na terra ficará desligado nos céus" (Mateus, 16:18-9 e 18. A Bíblia, 1995: 1213 e 1216).

Como lembram Souza e Barbosa, a única sociedade a se levar em conta, neste raciocínio, é a Ecclesia. Pois é dela que fazem parte, por meio do batismo, todos os fiéis. Razão pela qual ela tem de ser governada por uma única cabeça: segundo as Escrituras, o sumo pontífice. Não obstante a insistência do pontífice, a contenda entre a Igreja e o Império pelos respectivos âmbitos de jurisdição seguia adiante.

Tempos depois, Inocêncio III, na bula Venerabilem, de 1202, acrescentava mais uma pedra à construção hierocrática. Nela, ele lembrava aos príncipes eleitores germânicos de que eles de fato escolhiam livremente o seu monarca. Mas que era apenas por meio da unção e da coroação pelo Papa, ou por seus devidos representantes, que o imperador seria sagrado. Lembrava ainda que o Papa Leão III (795-816) havia feito a translatio imperii dos gregos para os germânicos, na pessoa de Carlos Magno (800-814), no Natal de 800.

Desse modo, declarava Inocêncio, o Império ficara sob a auctoritas do bispo de Roma e devia ser entendido como um beneficium (favor, graça) eclesial, outorgado pelas regras do direito canônico. O imperador seria, portanto, beneficiário (vassalo) da Igreja e teria a obrigação de defendê-la. Inocêncio III completava assim a inversão histórica referente aos primórdios da relação entre regnum e sacerdotium, tal como registrada nos escritos do século IX e descrita por W. Ullmann, ${ }^{8}$ entre outros.

Pela primeira vez na complexa história desses dois poderes, o pontífice reivindicava caber o exame quanto à aptidão e ao caráter do candidato ao trono imperial à avaliação e decisão do Papado. Nos termos do pontífice, na bula Venerabilem:

Mas, por outro lado, os príncipes devem reconhecer e decerto reconhecem que a autoridade e o direito para examinar a pessoa eleita rei e que será promovida ao Império nos compete [ao Papado], visto que nós a ungimos, coroamos e consagramos. Pois é normal e regularmente observado que o exame da pessoa compete àquele que lhe vai impor as mãos. Por conseguinte, se os príncipes, em consenso ou em desacordo entre si, escolherem como reis uma pessoa sacrílega ou excomungada, um tirano ou um idiota, ou um herege ou um pagão, nós deveremos ungir, consagrar e coroar tal pessoa? Decerto que não! (Souza e Barbosa, 1997: 131). 
E, mais adiante, no $₫ 6$, Inocêncio III esclarecia o grau de intervenção temporal que reivindicava: decidir quem seria escolhido imperador em caso de indecisão ou contestação. ${ }^{9}$ Oitenta anos mais tarde, invertia-se deste modo em favor do Papado o direito de resolver eleições contestadas - direito antes concedido ao imperador Henrique $\mathrm{V}$ pelo papa Calixto II, no documento que selou a paz entre os dois poderes em 1122: a concordata de Worms.

Inocêncio também avançava na construção dos pilares de uma teoria hierocrática do poder quando conferia à Igreja o papel de sede última de legitimação do poder temporal, a partir de seus próprios critérios políticos e morais. Ficava finalmente estabelecida, ao menos na teoria, a primazia do sacerdotium sobre o regnum, com o pontífice na função de juiz supremo, fosse em assuntos espirituais fosse em assuntos seculares. Daqui para frente, os papas reivindicariam o direito de só tratarem alguém como imperador depois de sua eleição para o cargo ter sido sancionada pela Ecclesia.

Esse arbítrio autoconcedido pelo papado se manifestou em inúmeros outros episódios da época. Um caso conhecido foi o do rei franco Filipe Augusto (1180-1223), cujos filhos com Inês de Meran haviam sido reconhecidos como herdeiros legítimos pelo pontífice. Pouco depois, Inocêncio III negou o mesmo pedido ao conde Guilherme de Montpellier, explicando-lhe que ao rei dos francos o pedido fora concedido em virtude de não reconhecer o rex superior algum na esfera temporal. Por isso (por não ter um superior temporal), Filipe recorrera à autoridade pontifícia, sem que seu ato lesasse o direito de outros, o que já não cabia ao conde, subordinado legalmente pelos laços de vassalagem ao rei. ${ }^{10} \mathrm{E}$ explicava sua decisão nos seguintes termos:

Movidos por essas razões e baseando-nos, tanto no Antigo, como no Novo Testamento, atendemos à solicitação de Filipe, tendo em mente ainda que, não só no Patrimônio da Igreja exercemos pleno direito temporal, mas também noutras regiões, dadas certas circunstâncias, exercemos casualmente a jurisdição na esfera secular. Com isso não tencionamos prejudicar um direito de outrem, ou usurpar um poder que nos seja indevido, visto não ignorarmos a resposta que Cristo oferece no Evangelho: "Dai a César o que é de César e a Deus o que é de Deus" (grifo meu) (Per venerabilem. Souza e Barbosa, 1997: 135).

Mas a argumentação de Inocêncio III não parava aí. O próprio apóstolo Paulo já havia explicado, escrevia ele, que a plenitude de poder inclui, quando necessário, a execução de incumbências seculares. E para sustentar sua argumentação, Inocêncio apoiou-se no Deuteronômio, associando-o à passagem de Mateus relativa ao mandato e ao primado petrinos. Diz a passagem bíblica: 
Se for muito difícil para ti julgar da natureza de um caso de sangue derramado, litígio ou ferimentos - questões levadas ao tribunal de tua cidade - , por-te-ás a caminho para subir ao lugar que o Senhor, teu Deus, tiver escolhido. Irás procurar os sacerdotes levitas e o juiz que estiver em função naquele dia; e os consultarás e eles te comunicarão a sentença. Procederás conforme a sentença que te houverem comunicado no lugar que o Senhor tiver escolhido, e cuidarás de por em prática todas as suas instruções. Segundo a instrução que te tiverem dado e segundo a sentença que tiverem pronunciado, procederás, sem te desviares da palavra que te tiverem comunicado nem para a direita, nem para a esquerda. Mas o homem que tiver agido com presunção, sem escutar o sacerdote que lá estiver oficiando em honra do Senhor, teu Deus, e sem escutar o juiz, este morrerá (Deuteronômio 17:8-12. A Bíblia, 1995:224).

Com Inocêncio III, a teoria hierocrática que crescia dentro da Igreja acrescentava em seus fundamentos argumentos extraídos de uma leitura mais pragmática tanto do Antigo quanto do Novo Testamento. Além de um novo uso da Escritura, Inocêncio consolidava a esfera de atuação e legislação da Ecclesia, tornando inquestionáveis suas decisões no foro espiritual e ampliando seu raio de ação para os assuntos temporais. Isto é, afirmava a plenitudo potestatis do Papa não mais apenas no âmbito espiritual, mas agora também in temporalibus. ${ }^{11}$

Embora o papado ainda não dispusesse, nesse momento, de uma teoria organizada da supremacia do poder espiritual sobre o temporal, como aquela que seria oferecida, por exemplo, um século depois pelo canonista Egídio Romano, os elementos necessários à reivindicação da plenitude de poder pelo pontífice já estavam colocados. ${ }^{12}$ Não havia mais dúvidas de que o Papa constituía a única autoridade legítima para decidir em assuntos religiosos. A pretensão agora era mostrar que sua auctoritas se estendia também à esfera da dominação temporal.

Uma nova contenda entre Papado e Império não tardou a ocorrer e daria ensejo a novos avanços por parte da Ecclesia. O episódio agora era a excomunhão do imperador Frederico II (1212-1250) pelo Papa, em virtude da sua pretensão de conquistar pelas armas o Patrimônio de São Pedro e da perseguição religiosa e confisco de bens eclesiásticos promovidos pelo imperador nos seus territórios. A disputa acirrou-se ainda mais com a eleição de Inocêncio IV (1243-1254) a sacerdote máximo da Ecclesia.

No Concílio de 1245, Inocêncio IV depôs Frederico, acusando-o de perjúrio, sacrilégio, de manter relações amistosas com os infiéis, de violar a paz entre Papado e Império, de ser omisso no cumprimento de seus deveres como minister Ecclesiae e "outros crimes", conforme consta na Sentença de deposição do 
Imperador Frederico, de 1245. O imperador, em resposta, escreveu e divulgou em toda a cristandade a Encyclica contra depositionis sententiam, na qual se defendia. Inocêncio IV respondeu então, na bula papal Aeger cui lenia, a cada uma das críticas feitas por Frederico II.

Segundo especialistas, esse pode ser considerado talvez o mais enfático documento de Inocêncio IV em favor da hierocracia. Nesta bula, o pontífice afirmava ser o sumo sacerdote o vigário terreno de Cristo - "Rei dos reis"- e o sucessor de São Pedro. Nessa condição teria recebido do filho de Deus uma generatis legatio, que lhe conferiria jurisdição plena sobre todos os homens, inclusive sobre os governantes terrenos, o que lhe permitia dar ordens quando e a quem desejasse. Nos termos do documento, pode-se perceber a força da convicção que movia o sumo sacerdote:

De fato, o Senhor Jesus Cristo, Filho de Deus, Deus e homem verdadeiro, agindo também como autêntico rei e sacerdote, segundo a ordem de Melquisedeque, igualmente revelou de modo claro aos homens [...] que estabeleceu na Sé Apostólica uma monarquia não apenas sacerdotal, mas também real, ao confiar ao bem-aventurado Pedro e aos seus sucessores as rédeas dos impérios celeste e terrestre, como se pode notar de modo evidente em razão da pluralidade das chaves, de maneira que através de uma recebemos o poder sobre a terra e as questões seculares e, pela outra, no céu e a respeito dos assuntos espirituais, a fim de que se entenda que o Vigário de Cristo obteve o direito de julgar. [...] (grifos meus). (Aeger cui lenia. Souza e Barbosa, 1997:144-145)

Os sacerdotes do Antigo Testamento, prosseguia Inocêncio IV, receberam de Deus semelhante poder, fato que lhes tinha permitido depor os maus governantes de Israel. Do mesmo modo, o sumo pontífice podia intervir nos assuntos temporais quando os governantes seculares não cumprissem com os seus deveres para com Deus e para com a Igreja. E isso porque Cristo, obedecendo aos desígnios do Senhor, estabeleceu na Igreja um principado sacerdotal e real, dado que ele é ao mesmo tempo sacerdote e rei. É por esta razão que extra Ecclesia nullum dominium. ${ }^{13}$

Apesar de todas as acusações que lhe pesavam, Frederico manteve-se no trono até a morte, em 1250. Pouco antes de morrer, no entanto, enviou a toda cristandade uma carta na qual declarava a intenção do pontífice de assassiná-lo. $\mathrm{O}$ que teria dito Hobbes sobre um tal desfecho?

A ideia, tão cara aos autores absolutistas que se seguiriam, de que a vontade do soberano, e não a justiça, constituía o elemento essencial da lei foi posta por um canonista do século XIII, Laurêncio Hispano, contra uma das mais fir- 
mes tradições da política medieval. Separando a vontade do príncipe - no caso, o sumo sacerdote - do conteúdo da lei, Hispano tornava a lei plenamente caracterizável sem referência à moralidade ou a qualquer conceito transcendente de justiça. Esse é um exemplo de como, aos poucos, delineava-se a noção da vontade (auctoritas) como fonte da lei.

Embora a ideia do predomínio da norma (e da justiça) tenha permanecido como ideologia dominante no século XIII, a questão das relações entre o príncipe e a lei já vinha sendo revista desde o século XII. No final deste, os canonistas já utilizavam o termo ius positivum para indicar a lei promulgada pelo legislador humano (Pennington: 1991: 425).

Ao apontar a vontade do príncipe como fonte da lei, separando lei e justiça e, portanto, vontade legisladora e razão, Laurêncio Hispano abria uma perspectiva nova para a concepção do poder. No entanto, segundo ele, mesmo o exercício "não razoável" do poder teria de ser legal. Outros canonistas o acompanhavam, distinguindo a autoridade do príncipe da "moralidade" da lei. Mas, ao mesmo tempo, enfatizavam a obrigação do príncipe de se sujeitar à norma por ele estatuída.

Tal como Laurêncio Hispano, também o Ostiense, partidário da causa papal, terminou desenvolvendo a noção de plenitudo potestatis, contribuindo assim para o refinamento do conceito. Também segundo ele, a vontade do princeps - em sua concepção, o pontífice - era a fonte da lei. Não se limitava pelo rigor da razão e da moralidade, e, sob certas circunstâncias, o monarca poderia violar os preceitos de justiça. Dados todos esses pontos, conclui Pennington, estavam presentes os elementos necessários para se pensar o que mais tarde se chamou "razão de Estado" (Pennington: 1991: 436).

Pennington lembra que os canonistas utilizaram essas ideias para estabelecer os limites constitucionais da autoridade papal. O alcance dessa autoridade era definido pela noção de plenitudo potestatis, que em pouco tempo seria adotada também para descrever o poder legítimo, pouco depois denominado soberano, da monarquia secular.

\section{Conclusão}

A partir da argumentação levada a cabo até aqui, torna-se possível sustentar com alguma convicção a ideia de que as questões vinculadas à noção de soberania eram simultaneamente políticas e jurídicas. Eram políticas porque envolviam a construção de um sistema de poder, fosse ele hierocrático ou estatal. E eram também jurídicas porque todas as pretensões eram apresentadas como legais. O que se refazia, nesse período, não era apenas uma constelação de forças, mas toda uma ordem normativa. 
A ideia nascente de soberania já podia nesse momento ser captada em suas diferentes funções: 1) como direito reivindicado e, portanto, objeto de controvérsia jurídica; e 2) como atributo do poder, qualidade política que se manifestava, simultaneamente, como autoridade suprema e como independente de qualquer outro poder terreno. E os papas juristas que se sucederam trataram de explicitar esses pontos.

Esquematicamente, a construção da ideia de soberania ocorria em dois momentos. No primeiro, o grande tema era o da distribuição das jurisdições num sentido restrito. Tratava-se de saber, sobretudo, quem fazia cumprir as leis. A autoridade disputada era principalmente judiciária. No segundo momento, emergiria o problema do poder legislativo, tal como entendido modernamente. Jurisdição, a partir daí, passaria a incluir também o direito de criar, de mudar e de revogar normas.

A imagem de um legibus solutus, isto é, de um legislador absoluto, oriunda do direito romano, já reaparecera em glosadores como o italiano Azzone e o inglês Alan, no fim do século XII. No entanto, a ideia da lei como expressão de uma vontade soberana, fonte única de validade da norma civil, só se cristalizaria com alguma lentidão. A noção do princeps legibus solutus deve ser entendida de forma variável entre as primeiras grandes discussões, no século XI, e a sua tradução radical na obra hobbesiana.

De modo esquemático, seria possível descrever esse desenvolvimento como um percurso entre dois extremos. Num deles, a lei (natural, divina, costumeira, estatuída ou positiva) sobrepunha-se totalmente ao príncipe (lex facit re$\mathrm{gem}$. No outro, a vontade soberana era fonte criadora, transformadora e revogadora da lei. Como todo esquematismo, esse deve ser considerado com reserva, porque o voluntarismo já aparece no século XIV e a noção de uma ordem anterior e superior à vontade ainda seria visível por muito tempo na literatura política moderna.

Mas aquela ressalva, a da evolução, é indispensável. Ela acentua a ideia de um processo formador. E, como se procurou demonstrar, um processo cujo refinamento conceitual foi operado em grande medida pelos teóricos da Igreja e do poder do sumo pontífice. Seus resultados logo seriam apropriados pelo e incorporados ao conjunto dos poderes do Estado e de seu representante máximo. Ninguém menos do que Thomas Hobbes iria imortalizar a teorização de canonistas como Laurêncio Hispano e o Ostiense acerca da ideia de soberania na sua famosa máxima auctoritas, non veritas, facit legem. Seria apenas com a emergência de uma nova forma de organizar as relações de poder na sociedade - o Estado moderno que as noções de Estado e soberania passariam a ser concebidas como duas faces de uma mesma moeda. 
1. Marcel David afasta sem muita dificuldade a objeção do anacronismo. Depois de examinar o uso dos termos soberano e soberania nos séculos XIII e XIV, ele põe na mesa um argumento muito mais importante: nos séculos XII e XIII, "três das noções expressas em francês pela palavra soberania já existem, simplesmente adaptadas à estrutura da sociedade política do tempo. Duas delas, autoridade suprema e recusa de toda ingerência de um superior no nível de uma potência reconhecida como legítima, se exprimem pela mesma palavra: auctoritas. Quanto à potência pública, é a palavra latina a partir da qual ela se formou, potestas, que habitualmente serve para exprimi-la. Assim, o pensamento político dessa época soube fazer do vocabulário um uso mais judicioso do que a partir do século XVI" (cf. David, 1954: 14).

2. O nicolaismo foi o nome que se deu à prática do casamento clerical dentro da Igreja. Já a simonia, como lembra Ian Robinson, havia sido definida, inicialmente, como a venda de uma ordenação sacerdotal por um bispo. Mais tarde, o termo foi expandido, passando a recobrir todo o tráfico de coisas sagradas. No século XI, era mais frequentemente usado para designar a venda do cargo de bispo ou abade pelo governante secular (cf. Robinson, 1996: ix).

3. O medievalista alemão Gerd Tellenbach, resumiu esta disputa de maneira clara e precisa: segundo ele, a batalha entre realeza e sacerdócio constituía um problema de dois poderes fundados por Deus. E a grande disputa da época era a de decidir se um deveria se submeter ao outro, ou se deviam ser considerados dois poderes independentes, tal como havia proposto Gelásio I (cf. Tellenbach, 1996: 352). Uma discussão bastante detalhada dos epi- sódios que envolveram a disputa pela investidura de bispos e abades pode ser encontrada em Tellenbach, 1996:185-303.

4. Uma boa introdução a esta multiplicidade de acontecimentos que marcaram o século XIII pode ser encontrada em Jeismann, 2000.

5. A reivindicação de Aleixo III apoiava-se na $1^{a}$ Epistola de São Pedro, em especial na seguinte passagem: "Sede submissos a qualquer instituição humana por causa do Senhor: quer ao rei, porque é o soberano, quer aos governadores, delegados por ele para punir os malfeitores e louvar as pessoas de bem. (...) Honrai todos os homens, amai vossos irmãos, temei a Deus e honrai ao rei".(1 $1^{a}$ Epístola de São Pedro, 2:13-17, cf. A Biblia , 1995: 1495-1496).

6. No documento original: "No entanto, $\mathrm{o}$ que foi legal na época do Antigo Testamento, agora sob o Novo Testamento é diferente, pois Cristo, que se fez sacerdote eternamente segundo a ordem de Melquisedeque, ofereceu-se como hóstia a Deus Pai sobre o altar da Cruz. Por sua morte, ele redimiu o gênero humano e realizou isto na condição de sacerdote, não como rei, e principalmente o que diz concerne à missão daquele que é o sucessor do Apóstolo Pedro e Vigário de Jesus Cristo" ("Decretal Solitae de Inocêncio III a Aleixo III de Constantinopla"; in Souza \& Barbosa, 1997: 130).

7. "Deus disse: 'Que haja luminares no firmamento do céu para separar o dia da noite, que eles sirvam de sinal tanto para as festas como para os dias e os anos, e que sirvam de luminares no firmamento do céu para iluminar a terra'. Assim aconteceu. Deus fez dois grandes luminares, o grande luminar para presidir o dia, o pequeno para presidir a noite, e as estrelas. Deus os 
estabeleceu no firmamento do céu para iluminar a terra, para presidir o dia e a noite e separar a luz da treva. Deus viu que isto era bom" (Gênesis, 1:14-18. In: A Bíblia, 1995: 11).

8. Cf. Ullmann, 1965: 66 e seguintes, e Mateus, 16:18-9 e 18:18. In: A Bíblia, 1995: 1213 e 1216.

9. "É evidente ainda que, numa eleição, quando os votos dos príncipes estão divididos, após uma advertência e um intervalo conveniente, podemos favorecer um dos postulantes, considerando-se que posteriormente um deles virá a ser ungido, coroado e consagrado por nós, e aconteceu freqüentemente que ambos nos pediram que fizéssemos isso. Assim, que brilhem o exemplo e o direito" (cf. Souza e Barbosa, 1997: 131 e seguintes).

10. “(...) Além disso, como o rei Filipe não reconhece de modo nenhum ter superior no âmbito temporal, sem nisso lesar o direito de outrem, pôde sujeitar-se e [de fato] submeteu-se à nossa jurisdição, quando talvez parecesse a alguém que ele pode-

\section{Referências bibliográficas}

AQUINO, São Tomás de. Summa teológica. Porto Alegre: Livraria Sulina/EDUFRSGrafosul (edição bilíngüe: latim-português), 1980.

BALL, Terence; FARE, James \& HANSON, Russell L.(eds.). Political Innovation and Conceptual Change. Cambridge: Cambridge University Press, 1989.

BARTELSON, Jens. A Genealogy of Sovereignty. Cambridge: Cambridge University Press, 1995 ria ter legitimado por si próprio, não como pai em relação aos seus filhos, mas na condição de Príncipe para com os súditos. Tu, no entanto, és conhecido como súdito de outrem. Daí que não pudesses sujeitar-te nesse aspecto, sem prejudicares assim o direito alheio, a menos que te autorizassem a fazê-lo, e ainda não gozas da autoridade para teres o direito de dispensar em tal questão" (Per Venerabilem. In Souza e Barbosa, 1997: 134-135).

11. A plenitude de poderes do papa se concebia completamente no terreno jurídico: em primeiro plano permaneciam o cargo e as leis, e os decretos dele emanados. A validade de um decreto em nada dependia da pessoa do pontífice. A ideia subjacente era a de que nenhum Papa sucedia a seu predecessor em suas funções papais, mas sucedia a são Pedro diretamente e sem intermediários (cf. Ullmann: 100 e 105).

12. Para o aprofundamento deste tema, ver Kritsch, 2002: 392 e seg.

13. "Fora da Igreja não existe poder legítimo" (minha tradução).
BEAUMANOIR, Philippe de. Coutumes de Beauvaisis. 3 vols. Paris: J. Picard, 1970.

$A B I ́ B L I A$ (tradução ecumênica; ed. Gabriel C. Galache). São Paulo: Loyola, 1995.

BIERSTECKER, Thomas J. \& WEBER, Cynthia (eds.). State Sovereignity as Social Construct. Cambridge: Cambridge University Press, 1996. 
BLACK, Anthony. Political Thought in Europe (1250-1450). Cambridge: Cambridge University Press, 1992.

BLOCH, Marc. A sociedade feudal. Lisboa: Edições 70, 1987.

BODIN, Jean. On Sovereignty. Ed. Julian H. Franklin. Cambridge: Cambridge University Press, 1994.

BOÉR, Nicolas. Relação entre a Igreja e o Estado no fim do século XIII e no início do séc. $X I V$ nos escritos de filósofos de Estado e de canonistas. Tradução da tese de doutoramento aceita pela Universidade Real Húngara "Pátzmány Péter", em 1938, apresentada para registro na FFLCH-USP, 1972.

BRACTON, Henry de. De legibus et consuetudinibus angliae. Organizado por George E. Woodbine. 2 vols. New Haven: Yale University Press, 1925.

BURNS, J. H. (ed.). The Cambridge History of Medieval Political Thought c.350-c.1450. Cambridge: Cambridge University Press, 1991.

CALASSO, Francesco. Medioevo del diritto. 2 vols. Milão: Dott. A. Giuffré, 1954.

- Gli ordenamenti giuridici del rinascimento medievale. Milão: Giuffrè, 1965.

CARLYLE, A.J. \& CARLYLE, Robert W. A History of Political Theory in the West. 6 vols. Londres: William Blackwood and Sons, 1903-1936.

COLEMAN, Janet. Dominium in Thirteenth and Fourteenth-Century Political Thought and its Seventeenth-Century Heirs: John of Paris and Locke, Political Studies, vol. XXXIII, $\mathrm{n}^{\circ} 1$, março de 1985, p. 73-100.

DE BONI, Luís Alberto. Filosofia na Idade Média, Veritas, vol. 38, $\mathrm{n}^{\circ} 150,1993$, p. 305-314. (org.). Idade Média: ética e política. Porto Alegre: EDIPUCRS, 1996.

D'ENTREVES, A. Passerin. The Medieval Contribution to Political Thought (Aquino, Padua and Hooker). Londres: Oxford University Press, 1939.

. La dottrina dello stato. Turim: G. Giappichelli, 1962.

DAVID, Marcel. La souveraineté et les limites juridiques du povoir monarchique du IXe au XVe siècle. Paris: Dalloz, 1954.

DUBY, George. As três ordens ou o imaginário do feudalismo. Lisboa: Estampa, 1982.

ERTMAN, Thomas. Birth of the Leviathan: Building States and Regimes in Medieval and Early Modern Europe. Cambridge: Cambridge University Press, 1997.

FETSCHER, Iring \& MÜNKLER, Herfried (Hrgs.). Mittelalter: Von den Anfängen des Islam bis zur Reformation. Band 2, Pipers Handbuch der politischen Ideen. Munique: Piper, 1993.

FINKE, Heinrich. Aus den Tagen Bonifaz VIII. Funde und Forschungen. Münster: Druck und Verlag der Aschendorffschen Buchhandlung, 1902.

FRIEDRICH, Carl J. La filosofía del derecho. México: Fondo de Cultura, 1964.

GEORGANTAS, M.G. De la notion de souveraineté et de son évolution. Lausanne: Imprimeries Reúnies, 1921.

GIERKE, Otto. Development of Political Theory. Nova York: Norton, 1939.

Political Theories of the Middle Ages. Cambridge: Cambridge University Press, 1938.

GILSON, Étienne. El espíritu de la filosofía medieval. Buenos Aires: Emecé, 1952

GRABMANN, Martin. Studien über den Einfluss der Aristotelischen Philosophie auf die mittelalterlichen Theorien über das 
Verhältnis von Kirche und Staat. In: Sitzungsberichte der Bayerischen Akademie der Wissenschaften. Philosophisch-historische Abtl., Heft 2. Munique: Verlag der Bayerischen, 1934.

HELLER, Hermann. Teoria del Estado. México: Fondo de Cultura, 1987.

HINSLEY, F.H. El concepto de soberanía. Barcelona: Labor, 1972.

HOLMES, George. A Europa na Idade Média: 1320-1450. Lisboa: Presença, 1984.

HUIZINGA, Johan. O declínio da Idade Média. Lousã: Ulisseia, s/d.

JEISMANN, Michael (org.) Das 13. Fahrhundert - Kaiser, Ketzer und Kommunen. Munique: C.H. Beck Verlag, 2000.

KANTOROWICZ, Ernst. The King's Two Bodies. A Study in Mediaeval Political Theology. Princeton, NJ: Princeton University Press, 1981.

KEEN, Maurice. The Penguin History of Medieval Europe. Harmondsworth: Penguin Books, 1991.

KELSEN, Hans. La teoria dello stato in Dante. Bolonha: Massimiliano Boni, 1974.

KNOWLES, David. The Evolution of Medieval Political Thought. Londres: Longmans Green and Co., 1962.

KRETZMANN, Norman; KENNY, Anthony \& PINBORG, Jan (eds.). The Cambridge History of Later Medieval Philosophy (1100-1600). Cambridge: Cambridge University Press, 1982.

KRITSCH, Raquel. Soberania: a construção de um conceito. São Paulo: HumanitasIMESP, 2002.

A caminho do Estado moderno: as raízes medievais de alguns de seus elementos formadores. Revista de Sociologia $\mathcal{E}$ Política, 23, 2004, p. 103-114.
- - Do comissariado de Deus à vontade do 'princeps': lei, autoridade e soberania no pensamento político medieval tardio. Dois Pontos, vol. 5, n. 2, 2008, p. 11-32.

LAGARDE, Georges de. La naissance de l'esprit lä̈que au declin du moyen age. 5 vols. Paris-Louvain: Béatrice-Nauwelaerts, 1956-1963.

LE GOFF, Jacques. A civilização do Ocidente medieval. 2 vols. Lisboa: Estampa, 1984.

McILWAIN, Charles H. Constitutionalism and Changing World. Cambridge: Cambridge University Press, 1969.

- The Growth of Political Thought in the West-from the Greeks to the End of Middle Ages. Nova York: Cooper Square,1968.

MIEHTKE, Jürgen. Kaiser und Papst im Konflikt-zum Verhältnis von Staat und Kirche im späten Mittelalter. Coleção Historisches Seminar, A. Reese \& U. Uffelmann (Hrgs.). Düsseldorf: Verlag Schwann-Bagel, 1988.

PASSOS, J. Afonso M. B. Bonifácio VIII e Felipe o Belo de França. Tese de doutoramento. USP: FFLCH-HIS, 1972.

ROBINSON, Ian Stuart. The Papacy (1073-1198): Continuity and Innovation. Cambridge: Cambridge University Press, 1996.

ROMANO, Egídio. (1929), De ecclesiastica potestate. ed. latina de R. Scholz, Weimar: Hermann Böhlaus Nachfolger HofBuchdruckerei und Verlagsbuchhandlung. O poder eclesiástico. trad. L. A. De Boni. Petrópolis: Vozes, 1989.

SABINE, George H. Historia de la teoria politica. 2 vols. México-Buenos Aires: Fondo de Cultura Economica, 1963.

SCHMITT, Carl. Théologie politique. Paris: Gallimard, 1988. 
SOUZA, José Antônio C.R. \& BARBOSA, João Morais. O reino de Deus e o reino dos homens. Porto Alegre: EDIPUCRS, 1997.

STRAUSS, Leo \& CROPSEY, Joseph (eds.). A History of Political Philosophy. Chicago: Chicago University Press, 1963.

STRAYER, Joseph. As origens medievais do estado moderno. Lisboa: Gradiva, s/d.

TELLENBACH, Gerd. The Church in Western Europe from the Tenth to the Early Twelfth Century. Cambridge: Cambridge University Press, 1996.

TIERNEY, Brian. Church Law and Constitutional Thought in Middle Ages. Londres: Variorum Reprints, 1979.

. Origins of Papal Infalibility, 11501530. Leiden-Colônia: Brill,1988.

Religion, Law and the Growth of Constitutional Thought,1150-1650. Cambridge: Cambridge University Press, 1983.

TIERNEY, Brian \& LINEHAN, Peter (eds.). Authority and Power. Studies on Medieval Law and Government. Cambridge: Cambridge University Press, 1980.

TILLY, Charles (ed.). The Formation of National States in Western Europe. Série: Studies in political development. Princeton, NJ: Princeton University Press, 1975.
TORRES, João Carlos Brum. Figuras do Estado moderno. São Paulo: Brasiliense, 1988.

ULLMANN, Walter. A History of Political Thought - the Middle Ages. Londres: Penguin Books, 1965.

- Scholarship and Politics in the Middle Ages. Londres: Variourom Reprints, 1978.

. The Individual and Society in the Middle ages. Londres: Methuen \& Co., 1967.

- The development of the medieval idea of sovereignty. English Historical Review. vol. LXIX, n ${ }^{\circ}$ CCL, 1949.
et. al. Bartolo da Sassoferrato. Studie documenti per il VI centenario. Milão: Giuffrè, 1962.

WEINREB, Lloyd L. Natural Law and Fustice. Cambridge, Massachusetts: Harvard University Press, 1987

WILKS, Michael. The Problem of Sovereignty in the Later Middle Ages. Cambridge: Cambridge University Press, 1963.

WOOD, Diana (ed.). The Church and Sovereignity c. 590-1918: Essays in Honour of Michael Wilks. Oxford: Blackwell, 1991.

\section{Resumo}

O objetivo deste artigo é discutir a contribuição do pensamento eclesiástico medieval tardio para a formação do conceito de soberania. Como o Estado moderno, tal conceito tem uma gênese demorada: é parte de um processo de transformação jurídica e política, do qual resulta um novo mapeamento do poder e das lealdades na Europa. A conformação desse novo sistema de poder tem como contrapartida a constituição de uma nova ordem jurídica. Essa ordem redefine os vínculos de comando e obediência, constituindo unidades políticas como áreas de jurisdição exclusiva e estabelecendo, entre essas unidades, relações de igualdade: nenhuma se reconhece como subordinada a 
outra. Todas essas questões podem ser entendidas como disputas de jurisdição. Trata-se de saber quem julga e quem pune delitos civis ou violações de normas religiosas. Os poderes de legislar, de mudar a lei, de resolver como última instância e de controlar o uso da violência constituem o que os autores modernos nomearam soberania. Apontar a contribuição dos chamados Papas juristas do século XIII para a formulação de alguns elementos centrais a esta definição é a tarefa a ser levada a cabo neste estudo.

Palavras-chave: Teoria política medieval; soberania; império; papado.

\begin{abstract}
The aim of this article is to discuss the contribution of the late ecclesiastical medieval thought for the construction of the concept of sovereignty. Like the modern state, this concept has a long genesis: it is part of a process of legal and political transformation, which provided a new mapping of power (relations) and loyalties in Europe. The building of this new system of power has the creation of a new legal order as its counterpart. Such a new order redefines the bonds of command and obedience, constitutes political units as areas of exclusive jurisdiction and establishes among these units relations of equality: none of them understands itself as subordinate to another. All these questions can be understood as disputes over jurisdiction: who judges and punishes civil crimes or violations of religious rules? The powers to legislate, to change the law, to decide as the final instance and to control the use of the force constitute what the modern authors named sovereignty. The objective of this paper is to show the contribution of the so called lawyers popes of the thirteenth century to the development of some key elements of the notion of sovereignty.
\end{abstract}

Key words: Medieval political theory; sovereignty; imperium; papacy.

\title{
Résumé
}

L'objectif du présent article est de discuter la contribution de la pensée ecclésiastique du Bas Moyen-Age à la formation du concept de souveraineté. Ainsi que celui d'Etat moderne, ce concept naît d'une longue gestation: il fait partie d'un processus de transformation juridique et politique qui aboutit à une nouvelle distribution, en Europe, du pouvoir et des liens de loyauté. La conformation de ce nouveau système de pouvoir a comme contre-partie la constitution d'un nouvel ordre juridique. Cet ordre vient redéfinir les liens de commandement et d'obéissance, constitue des unités politiques en districts de juridiction exclusive et établit, entre ces unités, des relations d'égalité: aucune 
de ces unités se reconnaît comme subordonnée à une autre. Toutes ces questions peuvent être vues comme des disputes de juridiction. Il s'agit de savoir qui juge et qui punit les délits civils ou les violations des normes religieuses. Le pouvoir de légiférer, de changer la loi, de décider en dernière instance et de contrôler l'usage de la violence constituent ce que les auteurs modernes ont appelé souveraineté. Montrer la contribution des dits papes juristes du XIII ${ }^{\text {ème }}$ siècle à la formulation de quelques éléments centraux de cette définition est la tâche que nous nous proposons dans cette étude. Mots-clés: théorie politique médiévale; souveraineté; empire; papauté. 